\title{
Communication and Consciousness in the Pragmatist Critique of Representation
}

\author{
W. James and C. S. Peirce
}

Edmundo Balsemão Pires

\section{OpenEdition}

\section{Journals}

\section{Electronic version}

URL: http://journals.openedition.org/ejpap/864

DOI: 10.4000/ejpap.864

ISSN: 2036-4091

\section{Publisher}

Associazione Pragma

\section{Electronic reference}

Edmundo Balsemão Pires, « Communication and Consciousness in the Pragmatist Critique of Representation », European Journal of Pragmatism and American Philosophy [Online], III-1 | 2011, Online since 01 July 2011, connection on 19 April 2019. URL : http://journals.openedition.org/ejpap/864 ;

DOI : 10.4000/ejpap.864

This text was automatically generated on 19 April 2019

\section{(c) $(1)$}

Author retains copyright and grants the European Journal of Pragmatism and American Philosophy right of first publication with the work simultaneously licensed under a Creative Commons AttributionNonCommercial-NoDerivatives 4.0 International License. 


\title{
Communication and Consciousness in the Pragmatist Critique of Representation
}

\author{
W. James and C. S. Peirce
}

\author{
Edmundo Balsemão Pires
}

\section{Overview}

1 In many writings, W. James criticized the concept of a double of the object in the mind as a wrong perspective about the mental activity involved in the construction of the experience, a mistaken conception on the balance of the conscious and the unconscious aspects of the knowing process and, generally speaking, a misconception of the importance of the imaginative projections along the temporal emergence of the "actual" perception. His criticism applies also to the conventional Realist doctrines or to the modern theories of the perception as a mirror of the external being. But he didn't pay special attention to the linguistic extension of this "double" in the theory of sign and proposition of the modern philosophers that were continuing Aristotle.

2 Along Peirce's discussion of the Metaphysical and Logical significance of the Doctrine of Categories emerged the idea of a cyclical, sequential and self-catalysed sign-activity or semeiosis coupled with a much more complex triad of object, mental concept and sign than supposed in the classical and modern idea of representation. But, Peirce didn't extend his concept of a self-catalysed semeiosis to communication as a system autonomous from the individual consciousness and to biosemeiosis.

3 Additionally, If Peirce and James agree in the refusal of the conventional theory of representation as mirror, their rejection came from different horizons and their critiques don't mean the same. We will see if their views are convergent. 


\section{Consciousness}

\section{II.1. The Formation of Meaning in Consciousness}

4 The post-kantian Philosophy illustrates a continuous discussion about the meaning of the representation and the thing-in-itself in relation to the concept of the consciousness as absolute activity (Fichte) or the consciousness as a source of a subjective self-validating "certainty" (Hegel).

5 The writing of Kant's former student in Königsberg J. S. Beck, Erläuternder Auszug aus den critischen Schriften des Herrn Prof. Kant (Riga, 1793), includes a critique of the postulation of the thing-in-itself beyond the representation. According to J. S. Beck representations are the primitive source of knowledge in the consciousness and possibly its unique searchable source. The admission of the thing-in-itself transcending the representations would entail an avoidable concession to the dogmatic method in Philosophy, contradicting the spirit of the Kantian Philosophy.

6 Later, C. Renouvier began in his Essais de Critique Générale (first edition 1854) a philosophical programme ambitioning the rebuilding on new foundations of the critical Philosophy. He kept the essential traits of his earlier efforts in Le Personnalisme, suivi d'une Étude sur la Perception externe et sur la force (1903) where one finds chapters especially concerned with James's Philosophy of Perception and Will. ${ }^{1}$

7 Trying to preserve those Kantian conceptions akin to the positivistic imperative of the knowledge within the limits of "facts," one of the original contributions of the Essais is the refutation of Kant's dualism of the thing-in-itself and the phenomena. According to C. Renouvier Kant's dualistic thought remains uncritical and metaphysical and compels the philosopher to forge idola such as the noumenom. The objections regarding Kant's doctrine led to a sharp scrutiny of the concept of representation and to a refusal of the mirror version of the representation and Knowledge. The first division of his first Essai deals with the concept of representation (De la Repésentation en général). To be represented means simply "to appear." Appearance is the proper definition of a "representation." Thus, this word doesn't mean re-presentation of a previous thing, but donation of content in the consciousness. The relation between the representations and the external things is not clarified. Instead, the author states that in Knowledge the "things" must be referred only through the "representations." This requires a precision: if we can't apprehend anything outside the content of our consciousness all we need is this content. There is nothing more to know.

Identified with the conscious contents the "things" and the "representations" are the same. C. Renouvier calls these primitive contents "faits" or "phénomènes." The metaphysical problem of the relation between an "external world" and the conscious content of the representations ceases. "What is" is a representation as an irreducible phenomenon or "fact." From these premises comes the need for a new concept of experience. According to the "new criticism" experience refers to the multiple connexions of the phenomena in a personal consciousness. The form of the representations and the personal consciousness made a self-sufficient pair that makes senseless the problem of the access to a transcendent thing-in-itself: "la représentation n'implique rien qu'elle-même." ${ }^{3}$ It is the representation that divides itself in two faces: a representative and a represented. The idea of a self-division of the representation led to 
the refusal of the comparison of the consciousness with a mirror of the external thing. ${ }^{4}$ Finally, comes the statement of the identity between the thing and the appearance (phénomène).

9 In 1886, in the Beiträge zur Analyse der Empfindungen, according to a positivistic mood, E. Mach refused the thing-in-itself, independent from the impressions and sense-data of the experience (Merkmalen), as a sort of "rest" that would subsist as the transcendent warranty of the continuous multiplicity of the subjective impressions. Against the transcendence of a noumenon he declared: "Es ist denn richtig, dass die Welt nur aus unsern Empfindungen besteht." ${ }^{5}$ In the formation of the impressions one needs to describe the association between the states of consciousness and the space-time situation of the organic body. But from this relation it is not valid to conclude that there is an external independent support of the plurality of the impressions.

10 On the other hand, at the middle and final stages of the post-kantian period, A. Schopenhauer and F. Nietzsche prepared the conditions for a subjective genealogy of the thing-in-itself through its reduction to the human Will.

11 It is not incidental the inclusion of a Lecture on "Bergson and his Critique of Intellectualism" (Lecture VI) in James's Hibbert Lectures - A Pluralistic Universe. ${ }^{6}$ In the writings of the French philosopher James could find a metaphysical proof of the distinction of the psychic systems towards the physical and the biological, in the difference between the conscious, the organic and the inert realms. However, this distinction leads to the need for elucidation of the nature of the causation between the three levels. H. Bergson was very sceptical regarding the idea of a direct cerebral causation of the consciousness. ${ }^{7}$ His observations on the difference between the brain of the animals and the human brain made obvious that the human brain is structured in such a complex way that it liberates the superior form of consciousness one finds in humans. The complexity of the organization of matter in the living organisms establishes not only complex forms of life and consciousness, but the autonomy of consciousness properly speaking. L'Évolution Créatrice develops the connexion of the brain to the consciousness as an association between different orders of complexity that are mutually adapted in the universal process of Life. The mutual adaptation is possible because the Human brain doesn't dictate nothing qualitatively determined, but a certain number of possible combinations which the consciousness actualizes in a qualitative domain characterised by a permanent modal change of the actual in the potential and vice-versa. In the inner durée consciousness keeps the essential fluidity typical of all the organic structures in opposition to the inorganic matter and only along the stream of the psychic time the consciousness is close to itself. The knowing process emerges along the stream of time and consciousness Bergson called durée. This version of the cognitive process is very different from the intellectualist doctrine of representation that Bergson criticizes.

W. James refused the traditional theory of representation and along the section I of the Essays in Radical Empiricism he tried to develop his own version of the inner intentionality of consciousness. According to his version, the continuity of the experience is something that is achieved inside a series of connected moments of an unbroken stream of thought from a beginning point until a result. In such stream what is called the object or meaning is the result of this continuous, conjunctive, sequence of thinking. What compels to a relative pause of the thinking process, as its teleological orientation, is the cognitive interest of the cognisor and the action he associates to the particular sequences of the stream. Thus, what one calls the object is given in the immanent process of the 
continuous thinking as its (relative) teleological conclusion or terminus. The subject can give an account of such internal oriented procession until the meaning or object. But it is not possible to establish a correspondence part-to-part or point-to-point between the object of consciousness and the exterior thing. This means that the whitness of the inner connectivity of the thinking process doesn't give a precise picture of the whitness of the transcendent relations in what occurs in the physical world. The true experience is selfsufficient regarding its inner teleological tendency towards the meaning or object: "experience and reality come to the same thing." James criticized both the "representationalists" and F. H. Bradley because especially this one "derealized" the experience. ${ }^{9}$ His critic of the "absolutists" focused F. H. Bradley's Appearance and Reality as the direct target, and indirectly Hegel. I will not scrutinize here the accuracy of the indirect critiques against Hegel's Phenomenology of Spirit and Logic. a double of the original physical thing in the mind. The same applies to fictive substitutes of the physical thing. However, in the stream of thoughts it is possible to identify psychic processes where short thoughts, or concepts and ideas, operate by substitution of other more complex thoughts. But the value of this substitution is to be evaluated always regarding its function in the particular stream as a temporal continuous and not as tool to get out from the stream. a course of experience and substitutions are aspects in the transitions. Nothing in this field is able to operate definitely as a substitute for a physical thing or for an alien course of experience, because one can't abstract from the singular combination of possibilities that made the actual stream of thought possible which is individual, hic et nunc, and not repeatable. The equivalent of a "whole system of experiences" would be a "quasi-chaos" made by an indefinite combination of possibilities of stream paths and not an order. ${ }^{11}$ dualism of the thing-in-itself and its image in the mind supporting the thesis that every object of the type of a thought-correlate is identical to what is presented along the personal consciousness stream. The fiction of a point-to-point correspondence of a thought-correlate and an exterior substance is a prejudice rooted in grammatical fetishism. ${ }^{12}$

18 From the point of view of the jamesian Psychology grounded on the idea of homogeneity, continuity and indivisibility of the stream of thought it is expectable a critique of the psychological atomism of modern Philosophy (Hobbes, Locke and Hume). But in the constitution of its concept of the psychic representation, the atomistic reconstruction of thought and knowledge started from the postulate of the external thing with qualities figured in the mind through a physical-psychical causation. ${ }^{13}$ 
19 The psychological atomism brings together the parts of the mental object in order to show that those aspects were in the external physical object as the cause of the mental image. According to the description, a representation means a mental effect of an external cause through sensations and associations of sensations.

W. James remarks that this model takes the thought about the thing as equivalent to the objective discourse about the thing. The belief in the physical-psychical causation led to the suggestion of a previous unity in the external thing instead of the assumption of the homogeneity of the stream of thought. The causal model ignores that the time of the consciousness is not point-to-point identical with an objective chronology with its own parts or identical with the time of the discourse. ${ }^{14}$

21 Another consequence of the prestige of the atomistic Psychology was the description of the psychological objects as representations perfectly defined and separated from other representations equally distinct. However, a serious examination of the psychic enchainment shows that the distinct impressions are always referred to a halo or penumbra enveloping the psychic life. ${ }^{15}$

There is a corporeal, neural ground for this permanent shifting movement from the penumbra to the vivid impression along the stream. The neural transmission takes its own duration and its psychic effects are not comparable to discrete pulses. W. James distinguished the "brain dying vibrations" from the "brain vivid vibrations." Pauses in the neural vibration convert in memory marks and fictive substitutes. The cover of the pauses with the help of ficta is also a condition for the internal continuity of the consciousness. One may describe stream segments ordered around identity and relative durableness and other segments responsible for freshness. ${ }^{16}$ The resting-phases are like the "substantive parts" of the stream; the flux-phases "transitive parts." Thus, vagueness is a constitutive trait of the mental phenomena.

The difference between the "substantive" and the "transitive" is due to the selective orientation of the consciousness towards its elements. It is apparently inconsequential to say that consciousness is selective, but if one observes better $\mathrm{W}$. James was right when he extended such appreciation to the operations of the sensorial organs. One of the mental mechanisms that reveals this selective course is the attention. But selection through attention is associated with a variety of selective channels for the organization of the impressions, entailing complex negations, distinctions, abstentions, etc. ${ }^{17}$

Retrieving the problem of the coordination of the stream of consciousness and the world of the external things, W. James quoted Helmholtz ${ }^{18}$ to prove that what one calls "things" are results of impressions fixed through selections which set up clusters of qualities. These are arranged in such a way that our practical interests and habits dictate the relevancies regarding what occurs in the horizon of the mental meaning. Naming and the formation of judgments are the linguistic processes that follow.

The objective reference of a thought (or also, according to W. James, its "meaning") is not directly established by an isolated figurative act starting with the physical thing and ending in the mind but it is a temporal teleological oriented process towards an end or final meaning, where it is admissible differences between virtual stages in the formation of the meaning and actual, perceptual stages that fulfil the requirements for the conclusion of the stream of thought regarding the thing or event. This distinction shall be emphasized because a great part of our knowledge remains in the virtual stages. From the impossible fulfilment of all the conceptions of our virtual knowing follows that the 
"pragmatic method," which is a guessing about the practical consequences of our conceptions, is the best way to certify the correctness of our ideas. But in James's version, at the end, this method leads to a relative privilege of the perceptual elements of the experience regarding the other virtual psychic components. This is mainly due to a shift from the difference between vivid/non-vivid, virtual/actual and fictional/perceptual stages of the stream.

What are the criteria for the reaching of meaning? Is it the satisfaction with our picture of the real as a sort of positive emotional response to it? It coincides with the content of a "final" percept, as proposed by James? Or it stands for a felicitous momentarily "it fits" in a running process of adjustments of inner experience and bodily orientation?

If we choose the Jamesian answer to the alternatives and the idea of a tendency of the virtual knowing to the actuality of a percept there is no radical difference between the "pragmatic maxim" and verificationism that leads to a quasi representationalism. If we emphasize the value of the temporal drift, or the "in between," every moment of the experience is "virtual" and experience is a never ending path towards fulfilment. The exclamation "it fits" stands for a chance that happens when a selection is made from a variety of candidates such as a percept, fictional contents or emotions for the completion of a coherent picture of the stream of thought. It seems that James was not sufficiently radical to realize that in consciousness there is nothing definitely "actual" or "objective."

Our position regarding James's idea of virtual and actual (or perceptual) elements of the stream is twofold. Against James we say that meaning is not coincident with a final perceptual fulfilment of a flow. We are asserting that in consciousness alone there is no valid way to distinguish between actuality and virtuality. This distinction entails communicative events and not only consciousness contents. With James we agree that in consciousness meaning emerges from a temporal adjustment, and we add: it is a temporal adjustment of different elements of the experience in order to get the best layout for a puzzle, which belongs not to consciousness but to language in the form of propositions.

James declares that the stream of consciousness is a continuous flow of elements connected together along a nonstop chain. But in order to give an account of the objective reference of the thought he acknowledges a relative break in the chain to allow the formation of the consciousness of identity. However, it seems that he didn't realize that with the passage from the continuous flow to the consciousness of identity one is facing the emergence of a denotative symbolic action, which begins with imagination and at the end will mobilize names, the relation of names and verbs, or going to the point: language. From the perspective of consciousness as a nonstop metamorphosis of virtual and actual elements every meaning-fixation coincides with an interruption or with an internal reflexive loop. 
Figure 1

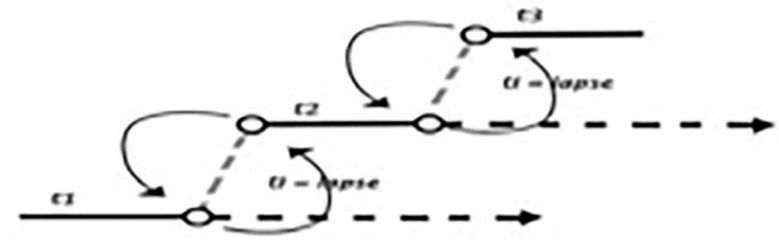
common to the idealists and to James's own conception. According to James the application of the idealist relation of the whole and the parts to the finite consciousness and to what he calls the super-consciousness has a major negative consequence or is paradoxical. In chapter III of Appearance and Reality F. H. Bradley started his explanation of the meaning of relations from the notion of the "given facts" as compounds or units made by qualities and relations. "Reality" is a composition of these two aspects. He claims that the way in which both dimensions harmonize is not immediately apparent and manifest. The conclusion of the argument points to a unifying principle that ties together relations and qualities: relation presupposes quality, and quality relation. ${ }^{19}$ It is impossible to dissolve qualities in relations or vice versa. The qualities must be and also must be related. This means that qualities are partially made by the relations. ${ }^{20}$ The connection between a quality and its relations constitutes a part of what a quality is, even if we know that the quality is never completely identical with its relational dimension. The part of the quality which depends on the relation is connected to it by an internal relation. The admission of internal relations is a consequence of the argument that states that a relation can't be a "mere adjective" to the qualities. ${ }^{21}$ Such outcome also entails the need for an adequate interpretation of the inherence of relations. Here, the objection can be turned to the empirical inaccessibility to such internal relations.

But James's critique of the super-consciousness in A Pluralistic Universe is directed towards both F. H. Bradley's ideas and J. Royce's full version of his "fourth conception of Being" in the Gifford Lectures The World and the Individual (1899-1900). The "fourth conception" states three basic thesis: $i$ ) that whatever is has its being only as a fact observed, and exists as the fulfilment of a conscious meaning;22 ii) the idea that the finite knowers are in reciprocal relations (in society) which leads to the conclusion that such reciprocal relation exists and, consequently is a fact and as a fact must be observed (again) by another 
consciousness, different of the first knowers; iii) to avoid a regressum ad infinitum J. Royce tries to prove that it must be a final knower, which is God identical with the Aristotelian "absolute self-knowledge," and concludes that "[...] one final knower knows all knowing processes in one inclusive act." ${ }^{23}$

In A Pluralistic Universe James's argumentation against intellectualism and idealism states that in the idealistic version of the process of knowledge the finite consciousness relates to a "super-consciousness" in the same way as a part to its whole. At the same time the difference of the finite and the super-consciousness is a difference for a consciousness and in this case for the super-consciousness, which means that the finite consciousness must be apparent and not real. Because this involves the rejection of the initial identity of appearance and reality the idealist supposition of a super-consciousness relating to the finite knowers as the whole to its parts must be false or the idealist thesis inconsistent and self-contradictory.

James's critique of the idealistic "whole and parts" relation is the ground for his strategic isolation of the consciousness as a special field, and a new disciplinary subject matter.

The "field of consciousness" can only be fully acknowledged under some general epistemological and ontological premises. I will detach four main ideas. i) The field of consciousness is self-sufficient regarding what appears for a consciousness; ii) the admission of this self-sufficiency and the rejection of a super-consciousness as another level of integrative knowledge of the finite subject entails the absolute individuation of the consciousness; iii) the ideas of pluralism and multiverse reflect the subtraction of the finite consciousness from its alleged source in the "absolute"; and iv) the space-time identity of the object is not a guaranty of the uniformity of the images of the world.

But these obvious consequences from the critical starting point against the monistic idealism produce the difficult alternative between a radical finite distribution of the "consciousness field" and the admission of a unifying principle. ${ }^{24}$ Some pages ahead James resumes and summarizes this dilemma in the alternative between the logic of identity or the irrationality. ${ }^{25}$

His choice will be on the side of the "irrational" character of psychical reality and life. But in order to make clear his choice he should explain what is "irrational."

The access to the inner, qualitative reality is only possible by a sort of participation, "direct acquaintance" or immediate experience of the proper or of an alien psychic life and not by rational, conceptual reconstruction.

Connected with his idea of the inner intentionality or immanent orientation of the stream of thought James has developed a conception of the physical environment of the consciousness and the relation to other minds. The thing-as-such was re-(ob)-jected to the environment in order to preserve the integrity of the unbroken connectivity of thoughts. The selfhood or personality of the stream of thought gives an additional complexity to our reading of James's pluralism: the other minds are also part of the environment of the psychic system. This is due to the fact that the reference to the consciousness is always reference to an intimate, individuated flow and the psychic systems are always split in individuated flows. Other flows of consciousness belong to a non-original, non-intimate given. If the access to other minds is mediated by the animated body of the others it emerges always as a symbolic, indirect reference through the analogical imagination, as also Husserl pointed out. ${ }^{26}$ 

or events is always tuned by mutual confirmation and the common reference to objects is frequently associated to the spatial location of the thing or event towards the organic bodies. The subject matter James didn't scrutinize was the relation of the common reference of the multiple individuated conceptions of the real to language and to communication. ${ }^{27}$ This lack leads, in the following remarks, to the recognition of the need for integration of the analogical imaginary projections of the "mine" and "yours" in language and communication.

Firstly, the habit to combine the immediate flow of consciousness and the stream of time in a unique course simply derives from the impossibility to have an intuition of time with no contents of consciousness, with no qualities of the experience.

Secondly, the continuity of the stream is made of sometimes imperceptible conscious and unconscious reflexive loops connecting memories, actual states and projections. In the conscious life, even the distinction between past and present entails reflexion. The virtual / actuality distinction in the conscious life refers to a difference in complex virtual, imaginary re-entries. similar to knotting points that work through dissimilar time strata in order to ensure the integrity of conscious life but not the continuity of time. The understanding of the way the loops work will lead us to a multilevel notion of time and consciousness, this one made of multiple streams and meta-streams (imaginary streams, virtual fluxes and fluxes representing fluxes) as an integration of the linear temporal succession (figured in the "arrow of time") and imaginary recursions of impressions and qualities of the experience.

Lastly, in the reflexive, symbolical, internal relations of streams and meta-streams one can't recognize parts standing to other parts as a representation towards an original or a teleological orientation of the virtual parts of the stream to perceptual fulfilments. This means that one can avoid the representational view of the understanding of the linkages within the conscious life without forcefully have to support the monolinear flow of time and consciousness. But the end of a flow has only compulsory value for the consciousness if one associates this stop with communicative events. Nothing in the immanent flow alone can stop its infinite virtual loop.

\section{Communication}

\section{III.1. Peirce's Transformation of the Concept of Representation Through the Sign-Relations}

46 These critical remarks ${ }^{28}$ will lead me now to C. S. Peirce's notion of thought as symbolic activity in order to evaluate if the semiotic examination of the process of thought is a better candidate to the critique of the traditional concept of representation..$^{29}$ Regarding my last critical remarks on the monolinear flow of time and consciousness, if Peirce's analogy of thought as a sign is true, then the "stream of thought" must be a reflexive internal loop only momentarily adhering to the so-called flow of time.

Observations on "representation" are documented in the seminal text On a New List of Categories (1868), based on a quasi-kantian double deduction of the categories from the judgements and the judgments from the acts of reduction to the unity of the multiplicity

European Journal of Pragmatism and American Philosophy, III-1 | 2011 
of the conscious content. Here, Peirce started with the psychological mechanism of attention, as "denotative power of the mind," to illustrate the operations of the mental life analogous of the diairesis and synderesis in propositions. This denotative power of the mind is turned to the flow of ideas and impressions and here it isolates something immediately present to the consciousness, that Peirce calls substance. ${ }^{30}$

In the investigation of the sources of the categories, the text distinguishes three internal references in the formation of judgments or in the application of predicates to the substances by the mediation of the copula or being: the reference to a ground, to a correlate and the reference to an interpretant. The analysis of the three internal references joins psychological, logical and semiotic aspects. The concept of representation is reserved to the general conceptions of the mind which can originate judgements, in a sense similar to Kant. Conceptions can be incomplete or complete. They are incomplete if they don't include the three references, but only one or two. They are complete whenever for the formation of the conception the reference to the interpretant is included. Likeness, Indices (or Signs) and Symbols are representations resulting from the reference to a ground (quality), to a correlate (by contrast and comparison) and to an interpretant (or mediating representation), correspondingly.

recognizing the validity of the medieval definition of Logic as the study of "second intentions" and identifying second intentions with the concepts of the understanding and the primary intentions with the objects, Peirce further characterized second intentions as "the objects of the understanding considered as representations." But he adds that such objects must be complete representations and not only icons or indices of their objects. In order to be complete representations they must include the interpretants. As complete representations all "second intentions" are symbols. From this conclusion comes the definition of Logic as the study of symbols and the triadic division of symbols in terms, propositions and arguments. The importance of the interpretant in the symbolic representation is evident. Thus, the conventional notion of representation was almost limited to icons and indices.

If Peirce's enlarged notion of representation is true one must apply the consequences of such enlargement to the total depth of the doctrines of categories which implies the psychological the logical, the semiotic and the ontological levels.

The 1868 text is not unequivocal concerning the definition of interpretant. Sometimes, it takes as a valid definition the equivalence between interpretant and translator. According to the best proposal of definition, an interpretant is a mediating representation which represents the relate to be a representation of the same correlate which this mediating representation itself represents (1.553). The exemplification that follows this definition in the text shows that Peirce intended with this "mediating representation" a thought operation that connects the object of a conception, the expression of the conception and the effect it produces in the mind(s). The equivalence between interpretant and translator as "mediating representation" is comprehensible if one remembers that the translator-interpretant is the responsible for the establishment of the identity of two different linguistic expressions of the same object in the mind. Thus, it is the translator the responsible for the causation of the identity or resemblance by mediating the linguistic difference.

The further evolution of the concept reveals even more the decisive aspect of such causality. The definition of representation follows: A representation is that character of a thing by virtue of which, for the production of a certain mental effect, it may stand in 
place of another thing. The thing having this character I term a representamen, the mental effect, or thought, its interpretant, the thing for which it stands, its object (1.564).

In On a New List of Categories was suggested the conceptual frame and terminology of the later work on semiotics in the Correspondence with Lady Welby, but here the division of the categorial space in Firstness, Secondness and Thirdness is achieved and mature.

In a way somewhat familiar to the late Wittgenstein and insisting in the triadic source of a complete deduction of categories, including the semiotic level of the analysis of signs, in his Questions concerning certain Faculties claimed for Man (1868) Peirce examined the question of the existence of thought without signs. His analysis led to the conclusion that "The only thought, then, which can possibly be cognized is thought in signs. But thought which cannot be cognized does not exist" (5.251). ${ }^{32}$

This means that the process of cognition entails a self-reflexive movement and doesn't coincide with the immediate, irreflexive, monolinear, temporal flow of consciousness or with the immediacy of the content of the inner experience.

On the other hand, the reductionist habit to reduce signs to the thought and the thought to the object (of perceptual content or intuition) is a consequence of the fear of a regressio ad infinitum in the process of the internal associations of the signs, as Peirce showed in his critique of Cartesian intuitionism.

But, Peirce kept the concept of representation.

Indeed, another justification for the non-reductionist thesis he also adduces lies on the fact that there is not a proper idea of thought without a notion of what it represents. He uses the concept of representation positively, as meaning the essential characteristic of the cognizing process. Because thought which cannot be cognized does not exist one needs to acknowledge the cognition as a process of meaning-donation of the thought. Thought is a process of self-enchainment where it is impossible to discover ultimate sources outside the flow. Such meaning-donation means representation through symbolic nexus in a cyclical chain. Sometimes, the symbolic nexus is also called "representation." However, with this word is meant the internal reference linking representamen, object and interpretant and not a reproduction of a given fact, "thing" or intuition.

This is clarified in the answer to Question 7 of Questions Concerning Certain Faculties Claimed for Man where Peirce declares ungrounded the belief in ultimate foundations of the enchainment of the thought and meaning-donation. ${ }^{33}$ His answer to this question means that the use of the grammar of causation in the relation of thought to its underpinnings is limited. We should use a model of a circular causation instead of the fiction of ultimate foundations. In his arguments, the critique of the causation of the flow of thought joins the idea that all the process of thinking supposes relations and is donated within relations: "[...] we know of no power by which an intuition could be known. For, as the cognition is beginning, and therefore in a state of change, at only the first instant would it be intuition. And, therefore, the apprehension of it must take place in no time and be an event occupying no time. Besides, all the cognitive faculties we know are relative, and consequently their products are relations. But the cognition of a relation is determined by previous cognitions. No cognition not determined by a previous cognition, then, can be known" (5. 262).

The reference to the relation of cognition to previous cognitions in a chain is not far from Bergson durée or James "stream." The distinct character of Peirce's enchainment lies on 
its symbolic-semiotic structure. The character of symbolic linkage of the thought-stream was developed along the pragmatic critique of the Cartesian intuitionism in The fixation of Belief (1877) and How to make our ideas clear (1878), as an aspect in the construction of the doctrine of the three categories. Additionally, the maturity of Peirce's critique of the prestige of the "clara et distinta perceptio" in 1877 and 1878 agrees with the formation of his theories on the scientific enquiry, the psychology of belief, the doctrine of the logical inference grounded on signs-relations and also the conviction of the identity of thought and sign-activity. These achievements constitute a system.

61 His notion of the role of the representations in mental life is never isolated from his understanding of the role of representations in the scientific endeavour or in the scientific ways to develop inferences which are communicative processes not reducible to mental states.

62 From the development of the theory of categories resulted the conclusion that the conception of what is entails a progressive determination of thought in an endless course, situated between the two extremities of the indeterminate firstness and the rules or laws for the recognition of the thought process itself, according to the thirdness. The secondness is defined by the actuality of action and reaction and it is identical with the sufficient maturity of thought to construct a fact. For that reason, Peirce wrote in A Guess at Riddle: It seems, then, that the true categories of consciousness are: first, feeling, the consciousness which can be included with an instant of time, passive consciousness of quality, without recognition or analysis; second, consciousness of an interruption into the field of consciousness, sense of resistance, of an external fact, of another something; third, synthetic conscious- ness, binding time together, sense of learning, thought (1.377). 34

\section{III.2. What is an Inference?}

In 1869, in Grounds of Validity of the Laws of Logic: Further Consequences of Four Incapacities continuing ideas from two other texts published in the Journal of Speculative Philosophy - Questions Concerning Certain Faculties Claimed for Man and Some Consequences of Four Incapacities (both from 1868) - Peirce suggested the figure of the absolute sceptic, unable to justify any sentence or belief, in order to establish his refutation of scepticism, the impossibility of an absolute beginning and his thesis that every judgement results from (previous) inference (stock of knowledge). Every inference accepts to be re- created in the syllogism: every S is M; M is P; then S is P. Such form is the habitual ground for ratiocination in everyday life producing a continuous chain of conceptions. This means that what is valid as real must have the characteristic of something engendered in a cognitive running process. From these assertions follow three main consequences: i) [...] real things are of a cognitive and therefore significative nature [...]; ii) to predicate something of another thing is equivalent to say that the first is a sign of the other; iii) cognition is a process of semiotic nature.

In the Logic of 1873 one may follow the essay to define inference in the scientific en- quiry from its grounding elements: ideas born from observations, formation of ideas through other ideas, development of ideas through inferential previous streams more complex. Peirce never isolates an inference from communicative connections. ${ }^{35}$ Psychic inferences of thought are thus mixed with communicative based inferences. On the other hand, the hypothetical nature of science explains that the inferences are never dead conclusions 
but prospective and conditional ways of disposing the known subjects. ${ }^{36}$ Disciplined inferences are methods. The convenience of the treatment of inferences as methods in the scientific enquiry is related to the creative orientation of the inferential stream towards the hypothetical (heuristic) activity of Science.

The requirement of self-sufficiency of the Cartesian intuitions limits the "clear and distinct perception" and the justified knowledge to a few moments in the psychic life and contradicts the continuity of the knowledge claimed for the scientific enquiry and common-sense through the illuminating power of guiding hypothesis or guessing. ${ }^{37}$ According to the article Logic (1873) and against Cartesianism, the normal movement of the scientific enquiry consists in a development from some temporary proto-beliefs which are general ideas able to start the inferential processes. Examples of proto-beliefs are the sensation and the observation. In the process of the scientific enquiry only observations are "real" inferential moments. Sensation is a starting point and a testimony of novelty in the thinking run but by itself it is not an inference. What Peirce calls the "final belief" is the consequence of this inferential process of fixation of the general opinion combining sensations and observations. In the case of the scientific enquiry the general opinion is not a solipsistic state of mind, but a consequence of a cooperative work in the formation of meaning and the cause of the general belief in a "community of research." This means that the philosopher gave to communication and not to consciousness, alone, the final responsibility for the formation of the belief and the construction of the Reality. ${ }^{38}$

From Peirce's writings we have no further explanation for the convergence of the psychic inferences and the communicative processing of meaning and information. We have to presuppose this convergence as already established. Thus, the heterogeneous character or relative autonomy of the conscious running of the inferences, with its ground in emotion and volition, and the communicative running of arguments and informationtransmission was not emphasized. However, we know that the faith in the immediate connection of the stream of consciousness and communication would be pure ingenuity. Peirce didn't give an adequate description of the enchainment of consciousness in communication and vice-versa. This remains a problem.

67 Certainly, the philosopher inverted the classical scheme of the representation and instead of conceiving the sign as a double of the thought-thing relation he took the sign as an activity characteristic of the thinking process itself, according to the famous definition of semiosis in Survey of Pragmatism: "By semiosis I mean [...] an action, or influence, which is, or involves, a cooperation of three subjects, such as a sign, its object, and its interpretant, this three-relative influence not being in any way resolvable into actions between pairs" (5.484).

er, Peirce didn't realize that consciousness and communication are two relative independent sources of meaning generation. ${ }^{39}$ Both participate in meaning, but through dif- ferent forms. The abstraction of the problem of the relative opacity of the psychic forms towards the communicative forms (and vice-versa) is reflected in the difficulty to realize how the final interpretants or the community's beliefs influence the actual running of a psy- chological experience in the individuals. This "influence" remains hypothetical or "regula- tive" in the Kantian sense. ${ }^{40}$

Former developments on the doctrine of categories from the years 1867, 1890, 1894, $1896-1897^{41}$ and the formulas of the sketches for the Lowell Lectures (1903), ${ }^{42}$ Lectures II and III, concerning the critique of the "nominalism" of modern Philosophy; the need for a 
recognition of "three types of Being" and three categories and here the regulative power of the "universals" (or generality) as "laws" concerning our representation of the future phenomena; the preparatory studies for the "existential graphs" entailing a concept of individuation, relation, possibility and necessity and the studies on abduction constitute the germinal material for Peirce's understanding of semiosis as a universal component of Being in general and for his own semiotic transformation of Pragmat(ic)ism.

In the formulation of the theory of the "three universes" contained in the Correspondence with Lady Welby (December, 14, 1908), and before another essay of a trichotomy of the sign-types, Peirce outlined a sketch of the embryonic three triads articulating the reality-thought-sign combinations.

Figure 2

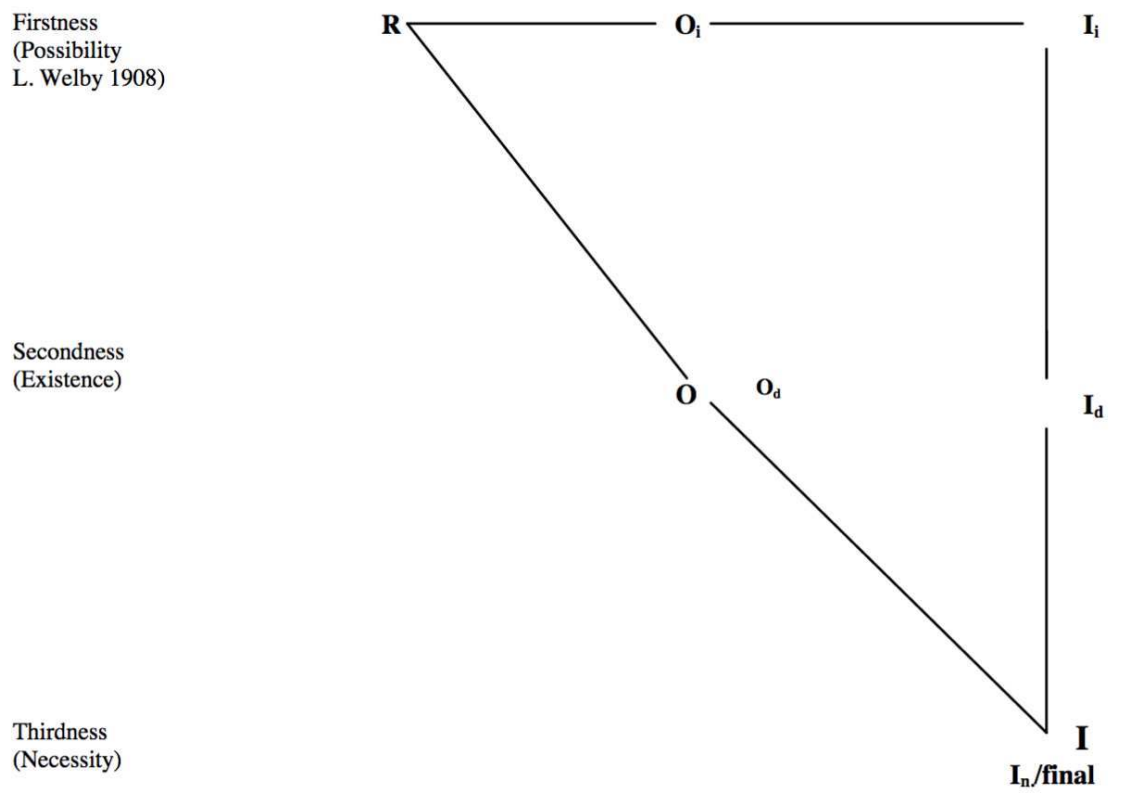

71 The resulting diagram represents the structure of the sign along the Representamen (R), Object (O) and Interpretant (I) links, with divisions occurring from its relative positions in the categories of the firstness, secondness and thirdness: Oi, Od, Ii, Id and If. The object (0) of the sign is divided in the types of the immediate (firstness) and dynamic (secondness); the Interpretant in immediate (firstness), dynamic (secondness) and final (thirdness). The Representament is not subject to divisions, because it coincides with the potentiality, typical of the firstness.

If Peirce's analogy of Man with a Sign stands for a radical, unrestricted, pan-semiotic model for the understanding of biological, psychic and communicative processes, it would contend with James's pluralism and the principle of the selfhood, intimacy and individuality of the psychic stream of consciousness and, additionally, it would violate the borders between biological, psychic and social systems. If this last conclusion was not the intended result of Peirce's analogy, even if some Peirce's texts point to a pan-semiotic model of this kind, one must harmonize the semiotic model with an internal pluralism of levels which will lead to the recognition of systemic autonomies. Such proposal demands a combination of semiotic and systemic models. According to this systemic and plural 
semiotic approach James's descriptions of the stream of consciousness would correspond to the psychic system with its own closure and borders formations and his claim to pluralism regains sense.

\section{III.3. The Double Environment Hypothesis and the Meaning of Modelling Systems}

73 If Peirce's semiosis supposes a complete communicative dimension and not only a linguistic comprehension of the use of symbols, this means that it is only by communication and not by language alone that one is able to follow the formation of some important systemic borders. A triple distinction of consciousness, language and communication is needed. For example, the distinction between the physical, exterior thing and the psychological object is only completed with the supposition of a public space-time system of coordinates which is only available through communicative sources. But communication is autonomous from the psychological formation of meaning in a great variety of modes.

Modern Society is an evolutionary demonstration of such progressive autonomy of the communicative emergence of meaning towards the "Psyché."

Inspired in the advances of Biosemiotics and in the writings of Y. Lotman and the Tartu School, the deepening of the concept of modelling systems led T. A. Sebeok to an enlarged notion of the modelling capabilities in systems subject to evolution, such as living systems, psychic systems and what he calls "cultural systems."

76 Modelling systems ${ }^{44}$ are enclosed spaces of semiotic and cognitive nature providing mappings of the world, adaptation responses to the environments, as "ecological niches," schemes for the processing of signalling information and the selection of patterns of behaviour appropriate to the circumstances of action or movement. The ability to develop models evolves from the basic organisms ${ }^{45}$ as pre-verbal and pre-linguistic mapping and adaptation to the complex images of the world of Science, Philosophy and Literature passing through the linguistic modelling systems. All these stages are partially related to representation, but with "representation" one doesn't mean passive reproduction of something given but mapping, selection, adaptation and coordination schemes. Further, a model is a congruent, self-referential set of schemes to anticipate and control the relation of cognitive orientations and action in complex organisms. Consequently, modelling is not an exclusive characteristic of the cognising psychic systems but occurs in biological, psychic and communication-based systems ${ }^{46}$ According to T. Sebeok's correction to Y. Lotman's concept of "secondary modelling systems," biological systems are the true primary modelling systems instead of linguistic systems which are secondary systems and "culture" and "cultural texts" are tertiary modelling systems. ${ }^{47}$ The criteria for primary, secondary or tertiary modelling systems depends on the degrees of increasing presupposition of the relevant environments. The tertiary modelling systems suppose the modelling results of the secondary systems.

Regarding the tertiary systems, I would prefer the concept of systems based on communication instead of "cultural systems," in virtue of our thesis about the distinction between the communicative forms of meaning and the psychic forms of meaning.

I would like to emphasise now that psychic systems and systems based on communication are parts of this integrative view of the "modelling systems." Both constitute models of 
the physical and biological environments and are models for each other, reciprocally. Each of them is the environment of the other. Language is an evolutionary tool for the accommodation of consciousness to the requirements of the participation in communication..$^{48}$ But language doesn't destruct the systemic autonomy of both systems, rather it presupposes such independence.

The hypothesis of a double or reciprocal environment supposes that meaning is the common element of both systems. What defines meaning is a minimal distinction that recurs in psychic life and in communication: the difference between actuality and potentiality.

W. James was aware of this basic oppositional repetitive relation at the foundations of the psychic processes of association, attention or, more generally speaking, of selection. The distinction also occurs in time, or we can interpret time as a universal generalization of the distinction of actuality and potentiality. However, the form of time is more universal than the forms of meaning in psychic or communicative systems.

81 Through the organic body the psychic system ensures a continuous contact with the physical and organic environment. Communication and communicative systems suppose the bodily coordination of the psychic systems towards their environments but the outcomes of communication are only significant for psychic systems or consciousness, because only psychic systems are able to decode communicative outcomes in their own elements, or thoughts. On the other hand, communication supposes the formation of the physical environment as an objective sphere regarding the "field of consciousness" which partially results from the closure of consciousness itself. The double environment is structured on the basis of a plurality of modelling schemes: biological, psychic and communicative. This multilevel architecture is worth of an autonomous analysis and remains a productive land for a multilinear Semiotic, refusing the abstraction of a naïve homogeneous model. ${ }^{49}$

Instead of conceiving representation as a doubling of the external being and a figurative passage between a physical state and a psychic replica the semiotic ideas of modelling and modelling systems consider the cognitive act of referring as a creation of the activity of modelling environments. What counts as the cognitive reference of a system shall be traced through the dividing border of the system, as its outer space. Such activity of drawing borders is one of semiotic nature because it is structured by the R-O-I relations. It is also systemic because gives to the object of the cognitive act of referring the status of an element in the environment of the system. Finally, it is evolutionary because supposes that the limits dividing system and environment are relative, contingent and evolve.

The adaptation of Peirce's gerative semiotic R-O-I model and his idea of semiosis as an endless process to the style of the systemic description made clear that the physical reality of the objects exterior to the mind is not the unique available environment, but one may conceive environments constituted by psychic or organic events and many others. Biological events or psychic streams may be parts of the environment of a system. This depends on which system is taken as reference. If one assumes that communication makes a self-reproducing cycle of connected elements distinct from consciousness and from the biological units, because in communication there is a connection of elements autonomous from the elements connected in the psychic stream of consciousness or in the self-reproduction of the living, then one faces the relation of communication to consciousness or to the organic events as a typical relation of a system towards its environment. 
James's and Peirce's approaches to pragmatism are so different in many aspects because they started from different systemic perspectives concerning the modelling activity and both believed in the universality of their own limited theoretical reconstructions of the partial modelling systems. The importance Peirce gave to the community in the endless formation of the "final beliefs," which are quasi identical with the final interpretants, clearly resulted from a communicative bias in the understanding of the modelling activity. On the other hand, James's quasi phenomenological description of the "field of consciousness" is a remarkable picture of the closure of the psychic systems coupled with the organic bodies, modelling the physical, external object or physical environment.

My proposal has an ontological depth. "What is" consists of the contingent outcome of overlapping environments: it is not a definite state in the world, a mental image or a communicative result of an endless communication process, but the overlapping of multiple modelling sources starting with the living mapping of the ecological niche until the conditional couplings of psychic and communicative modelling. This perspective gives an additional support to James's pluralism and multiverse.

The programme of a multilinear Semiotics implies a non-reductionist concept of reference, beginning with the constitutive couple of self-reference and hetero-reference that emerges when a system closes its own borders regarding its environments. The question of the generation of systemic borders is similar to the problem of the determination of "what is" real in a particular course of learning and adaptation and is therefore a question born in the cradle of Pragmatism and Peirce's Semiotics. But according to our multilinear programme evolution doesn't mean an overall uniform result, but entails differences in evolutionary stages and time discrepancies between the systems and the environments.

87 In order to know what is "real" one needs to know what reference-frames were settled to establish the difference between the reference framework, or "model", and what is going to be revealed through it. The $\mathrm{R} \rightarrow \mathrm{O} \rightarrow \mathrm{I}$ basic semiotic elements could be taken here as the elements of a gerative sequence of the emergence of the referential capability of systemic borders (self- and hetero-references).

On the division border between system (S) and environment (E) are closely associated three aspects of the semiosis: $i$ ) the distinction itself (S/E), like a separation between two "domains" - system and "world"; ii) the indication/signalling through which, thanks to a given operation, one of these domains may stand "in place of another", thus generating the familiarity I have been commenting between representation and meaning and, finally, iii) an enchainment of operations and codifications to rule the repetition of the former distinction (S/E). These three aspects reiterate in the gerative systemic terminology the semiotic distinction between $\mathrm{R} \rightarrow \mathrm{O} \rightarrow \mathrm{I}$. If the system refers to more than one environment, the three aspects must be applied to each of them.

The border between the system and the environment (S/E), the structuring difference between both domains, is situated at the level of the differential couples of the continuous/discontinuous and fusion/separation and can cause the enchainment of semiotic codes and operations sustaining or reinforcing meaning through repetition. In systems, the self-enchainment of operations (or elements) can be identified along the evolution as the possibility of repetition of the structural arrangement of a particular organism or machine. In order to reproduce the separation of the system regarding its environment $(S / E)$ is required the repetition of the original distinction which is reinforced through the 
evolutionary perception of identity of the same. Thus, sameness is obtained through repetition of a distinction (S/E) that recurs inside itself in virtue of an observation. This means the evolutionary attainment of self-reference.

\section{BIBLIOGRAPHY}

APEL K.-O., (1973), Transformation der Philosophie I-II, Frankfurt/M., Suhrkamp.

APEL K.-O., (1975), Der Denkweg von Charles Sanders Peirce, Frankfurt/M., reed. 1998, Suhrkamp.

AUSTIN J. L., (1962), How To Do Things With Words, Oxford, Clarendon Press.

BAINS P., (2001), “Umwelten,” Semiotica, 134-1/4, 137-67.

BALSEMÃo PIRES E., (1993), “Categorias e Semiosis. Notas introdutórias ao pensamento do individual em C. S. Peirce," Revista Filosófica de Coimbra, 3 (2), 115-68.

BARBIERI M. (ed.), (2008), Introduction to Biosemiotics: the New Biological Synthesis, Dordrecht, 2008, Springer.

BARTHES R., (1977), O grau zero da escrita seguido de Elementos de Semiologia, (translation), Lisboa, edições 70 .

BATTAIL G., (2009), “Applying Semiotics and Information Theory to Biology: A Critical Comparison," Biosemiotics 2, 303-20.

BECK J. S., (1793), Erläuternder Auszug aus den Critischen Schriften des Herrn Prof. Kant, Riga, Johann Friedrich Hartknoch.

BENVENISTE E., (1966), Problèmes de Linguistique Générale I-II, Paris, Gallimard.

BERGSON H., (1907), L'Évolution Créatrice, Paris, PUF.

BLACK M., (1962), Models and Metaphors: Studies in Language and Philosophy, Ithaca, Cornell University Press.

BLAU Joseph L., (1952), Men and Movements in American Philosophy, New York, Prentice-Hall Inc. Bosco N., (1959), La Filosofia pragmatica di C. S. Peirce, Torino, Edizioni de "Filosofia." BOUVERESSE J., (1971), La parole malheureuse: de l'alchimie linguistique à la grammaire philosophique, Paris, Minuit.

BOUVERESSE J., (1987), Le mythe de l'intériorité: expérience, signification et langage privé chez Wittgenstein, Paris, Minuit.

BRADLEY F. H., (1893), Appearance and Reality, London (sixth impression, corrected, 1916), George Allen \& Unwin Ltd.

BRENT J., (1993), Charles Sanders Peirce: A Life, Bloomington, Indiana University Press.

BRETON P. \& S. PROULX, (2002), L'explosion de la communication à l'aube du XXIe Siècle, Paris, La Découverte. 
BÜHLER K., (1934), Sprachtheorie: die Darstellungsfunktion der Sprache, Jena, Verlag von Gustav Fischer.

BURKS A. W., (1949), “Icon, Index and Symbol,” Philosophy and Phenomenological Research IX (1949), 673-89.

BUYSSENS E., (1943), Les langages et le discours. Essai de linguistique fonctionelle dans le cadre de la sémiologie, Bruxelles, Office de Publicité.

CARNOIS B., (1983), "La sémiotique pragmatique de C. S. Peirce et ses limitations

épistémologiques," Les Études Philosophiques, 299-316.

CONTE M. E. (ed.), (1977), La Linguística testuale, Milano, Feltrinelli.

DEELEY J., (2001), Four Ages of Understanding, Toronto, London, Buffalo, University of Toronto Press.

DEELEY J., (2004), “Tom Sebeok and the External World,” Semiotica 150 (1/4), 1-21.

Deledalle G., (1978), “Commentaire,” in Id. (ed.), C. S. Peirce Écrits sur le Signe, Paris, Seuil, 203-52.

DeLEDAlLe G., (1979), Théorie et pratique du signe. Introduction à la sémiotique de Charles Sanders Peirce, Paris, Payot.

DELEDAlLE G., (1989), Semiotics and Pragmatics: Proceedings of the Perpignan Symposium, Amsterdam, John Benjamins Publishing Co.

VAN DIJK T. A., (1984), Texto y Contexto (trans. of: idem, Text and Context, 1977), Madrid, Ediciones Cátedra.

DRESSLER W. U. (ed.), (1978), Current Trends in Textlinguistics, Berlin and New York, de Gruyter.

ECO U., (1968), La Struttura assente, Milano, Bompiani.

ECO U., (1983), Leitura do texto literário - Lector in fabula (translation), Lisboa, Presença.

ECO U., (1984), Semiotics and Philosophy of Language, London, Macmillan.

GALLIE W. B., (1966), Peirce and Pragmatism, New York, Dover Publiations.

GARCIA E. (ed.), (1974), El siglo de la Lingüística I-II, La Habana.

GURWITSCH A., (1964), The Field of Consciousness, Duquesne, Pittsburgh, Duquesne University Press. HJELMSlev L., (1975), Prolegomenos a uma teoria da linguagem, (translation) S. Paulo, Perspectiva. HONNEFELDER L., (1990), Scientia Transcendens. Die formale Bestimmung der Seiendheit und Realität in der Metaphysik des Mittelalters und der Neuzeit (Duns Scotus - Suaréz - Wolff - Kant - Peirce), Hamburg, Feliz Meiner Verlag.

ноок S. (ed.), (1950), J. Dewey: Philosopher of Science and Freedom, New York, Barnes \& Noble.

HOUSER N. \& C. KLOESEL (eds.), (1992), The Essential Peirce: Selected Philosophical Writings, vol.1, Bloomington, Indiana University Press.

Hоoкway C., (1985), Peirce, London and New York, Routledge and Kegan Paul.

HooKway C., (2000), Truth, Rationality and Pragmatism: Themes from Peirce, Oxford, Clarendon.

ноттоIS G., (1976), La philosophie du langage de Ludwig Wittgenstein, Bruxelles, Université Libre de Bruxelles.

JAMES W., (1907), Pragmatism, New York, Longmans, Green and Co.

JAMES W., (1909), A Pluralistic Universe, New York, Longmans, Green and Co. 
JAMES W., (1912), Essays in Radical Empiricism, New York, Longmans, Green and Co.

JAMES W., (1920), The Letters of William James (edited by his son Henry James) in Two Volumes, Boston, The Atlantic Monthly Press.

JAMES W., (1950), The Principles of Psychology, vols. I-II, New York, Dover Publications Inc.

JAMES W., (2008), A Pluralistic Universe (H. G. Callaway, ed.), Newcastle upon Tyne, Cambridge Scholars Publishing.

JAMES W., (2009), Essays in Radical Empiricism, Danvers, A General Book LLC Publication.

JAPY A. G., (1984), "Peirce's Third Trichotomy and Two Cases of Sign Path Analysis," Semiotica 49, $15-26$.

JOHANSEN J. D. \& S. E. LARSEN, (2002), Signs in Use. An Introduction to Semiotics, London and New York, Routledge.

KETNER K. (ed.), (1994), Peirce and Contemporary Thought: Philosophical Inquiries, New York, Fordham University Press.

JACQUES F., (1979), Dialogiques. Recherches logiques sur le dialogue, Paris, PUF.

JACQUES F., (1985), L'espace logique de l'interlocution. Dialogiques II, Paris, PUF.

LEECH G., (1983), Principles of Pragmatics, London, Longman.

LOTMAN Y. M., (1978), Estructura del Texto Artístico, Madrid, Istmo.

LOTMAN Y. M., (2001), Universe of the Mind: a Semiotic Theory of Culture (translation), Bloomington, Indiana University Press.

LOTMAN Y. M. \& B. A. Ouspenski, (1976), Travaux sur les systèmes de signes - École de Tartu, Bruxelles, Éditions Complexe.

Luhmann N., (2001), "Wie ist Bewußtsein an Kommunikation beteiligt," in Id., Aufsätze und Reden, Ditzingen, Reclam.

LUHMANN N., (2002), Einführung in die Systemtheorie, Heidelberg, Carl-Auer-Systeme Verlag.

мАСн E., (1886), Beiträge zur Analyse der Empfindungen, Jena, Fischer.

MARTY R., (1982), “C. S. Peirce’s Phaneroscopy and Semiotics,” Semiotica 41, 169-81.

MENAND L., (2001), The Metaphysical Club. A Story of Ideas in America, New York, Macmillan.

MOUNIN G., (1970), Introduction à la sémiologie, Paris, Minuit.

MORRIS Ch., (1937), Logical Positivism, Pragmatism and Scientific Empiricism, (Actualités Scientifiques et Industrielles), Paris, Hermann et Cie.

MORRIS Ch., (1938), Fondations of the Theory of Signs, in International Encyclopaedia of Unified Science, 1 (2), Chicago - London, University of Chicago Press.

MORRIS Ch., (1946), Signs, Language and Behavior, New York, Prentice-Hall.

MUller J. \& J. BRENT (eds.), (2000), Peirce, Semiotics and Psychoanalysis, in Psychiatry and the Humanities Series vol. 15, Baltimore and London, The Johns Hopkins University Press.

MURPHY M. G., (1993), The Development of Peirce's Philosophy, Indianapolis, Indiana University Press. NERLICH B., (1996), Language, Action, and Context: the Early History of Pragmatics in Europe and America, 1789-1930, Amsterdam and Philadelphia, John Benjamins Publishing Co. 
NÖTH W., (2006), "Yuri Lotman on Metaphors and Culture as Semiospheres," Semiotica, 161 (1/4), 249-63.

PARRET H. \& J. BOUVERESSE (eds.), (1981), Meaning and Understanding, Berlin - New York, de Gruyter. PARRET H., (1983), Semiotics and Pragmatics. An Evaluative Comparison of Conceptual Frameworks, Amsterdam, John Benjamins Publishing Co.

PEIRCE C. S., (1931-1966), Collected Papers of Charles Sanders Peirce edited by Ch. Hartshorne, P. Weiss and A. W. Burks, I-VIII, Cambridge, Massachusetts, The Belknap Press.

PEIRCE C. S., (1998), The Essential Peirce, Selected Philosophical Writings, 1893-1913, vol. 2, Bloomington, Indiana University Press.

PETRELli S. \& A. PONZIO, (2008), “A Tribute to A. Sebeok,” Biosemiotics 1, 25-39.

REILly F. E., (1970), Charles Sanders Peirce's Theory of Scientific Method, New York, Fordham University Press.

RENOUVIER C., (1854), Essais de critique générale, Paris, Librairie Philosophique de Ladrange.

REY A., (1976), Théories du signe et du sens II, Paris, Klincksieck.

RHEES R., (1998), Wittgenstein and the Possibility of Discourse, Cambridge, Cambridge University Press.

RICOEUR P., (1970), “Qu'est-ce qu'un texte? Expliquer et comprendre," in R. Bubner, K. Cramer, R. Wiehl (eds.), Hermeneutik und Dialektik II, Tübingen, J. C. B. Mohr.

RICOEUR P., (1975), La métaphore vive, Paris, Seuil.

RICOEUR P., (1986), Du texte à l'action. Essais d'herméneutique II, Paris, Seuil.

ROBINET A., (1978), Le langage à l'âge classique, Paris, Klincksieck.

RORTY R., (1961), “Pragmatism, Categories and Language,” The Philosophical Review, LXX (1961), 197-223.

RORTY R., (1979), Philosophy and the Mirror of Nature, New Jersey, Princeton University Press.

RosensoHn W. L., (1974), The Phenomenology of Charles S. Peirce: From the Doctrine of Categories to Phaneroscopy, Amsterdam, B. R. Grüner.

ROYCE J., (1900), The World and the Individual, First Series: "The Four Historical Conceptions of Being," New York, The MacMillan Company.

SAPIR E., (1921), Language. An Introduction to the Study of Speech, New York, Harcourt, Brace and Co. DE SAUSSURE F., (1916), Cours de linguistique générale, Paris, Payot.

SEGRE C., (1969), I Segni e la Critica. Fra Strutturalismo e Semiologia, Torino, Einaudi.

SEARLE J. R., (1983), Intentionality: an Essay in the Philosophy of Mind, Cambridge, Cambridge University Press.

SEBEOK T. A., (1994), Signs. An Introduction to Semiotics, Toronto, Buffalo and London, University of Toronto Press

SEBEOK T. A., (2001), Global Semiotics, Bloomington, Indiana University Press.

SIMON J., (1990), Filosofia da Linguagem, (translation), Lisboa, edições 70.

SPIRITo U., (1921), Il Pragmatismo nella Filosofia Contemporanea. Saggio Critico, Firenze, Vallecchi. 
SCHUTZ A., (1962), Collected Papers I - The Problem of Social Reality, "Common-Sense and Scientific Interpretation of Human Action," and "On Multiple Realities," The Hague, Martinus Nijhoff.

SCHUTZ A. \& T. LUCKMANN, (1973), The Structures of the Life-World, vol. I-II, Evanston, Northwestern University Press.

TABORSKY E., (1998), Architectonics of Semiosis, New York, St. Martin's Press.

VON UEXKÜLL J., (1956), Streifzüge durch die Umwelten von Tieren und Menschen - Bedeutungslehre, Hamburg, Rowohlt.

VON UEXKÜLL T., (1999), “The Relationship Between Semiotics and Mechanical Models of Explanation in the Life Sciences," Semiotica 127-1/4, 647-55.

VANDERVEKEn D., (1990-1), Meaning and Speech Acts I-II, Cambridge, Cambridge University Press.

VYGotsky L. S., (1993), Pensamento e Linguagem (translation), São Paulo, Martins Fontes.

WARTENBERG G., (1971), Logischer Sozialismus - Die Transformation der Kantschen

Transzendentalphilosophie durch Ch. S. Peirce, Frankfurt, Suhrkamp.

WIENER P. P. \& F. H. young (eds.), (1952), Studies in the Philosophy of Charles Sanders Peirce,

Cambridge, Massachusetts, Harvard University Press.

WitTGenstein L., (1922), Tractatus Logico-Philosophicus, London, Kegan Paul.

WITTGENSTEIN L., (1958), Philosophical Investigations, Oxford, Blackwell.

WitTGENSTEIN L., (1979), Über Gewissheit / On Certainty, Oxford, Blackwell.

WHORF B. L., (1956), Language, Thought, and Reality: Selected Writings of Benjamin Lee Whorf. Ed. J. B.

Carroll, Cambridge, Massachusetts, The Mit Press.

\section{NOTES}

1. W. James relationship with C. Renouvier is attested in many texts, including A Pluralistic Universe and the Letters. See for example W. James 2008: Appendix B, p. 233, n.24; W. James 1920: vol. I, p. 163-4; 206-7 (here James refers a course he gave on the subject of C. Renouvier's Essais), W. James 1920: vol. II, p. $44 \mathrm{ff}$.

2. "Les choses en tant que représentations, conformément à ce que je viens d'exposer, je les nomme des faits ou des phénomènes. Ainsi j'arrive à définir la chose par la représentation après avoir défini la représentation par la chose; et ce cercle est inévitable; et les deux mots représentation et chose, d'abord distingués, viennent se confondre en un troisième: phenomena" (Renouvier 1854: 7).

3. Renouvier (1854: 24).

4. "La connaissance ne reçoit point de représenté sans représentatif, point de représentatif sans représenté, et c'est dans une représentation qu'elle reçoit l'un et l'autre ; ailleurs jamais" (Renouvier 1854: 24-5).

5. Mach (1886: 8).

6. James (2008: 135-66).

7. Bergson (1907: 72).

8. James (2009: 20).

9. James (2009: 21).

10. James (2009: 22).

11. James (2009: 21). 
12. See the remarks about "the proper use of the term Object in Psychology" in James (1950: I, 275).

13. James (1950: I, 276-7).

14. See the illustration of the time of the "stream of thought" in James (1950: I, 279).

15. James (1950: I, 254-5).

16. James (1950: I, 242-3).

17. "The ubiquity of the distinctions, this and that, here and there, now and then, in our minds is the result of our laying the same selective emphasis on parts of place and time. But we do far more than emphasize things, and unite some and keep others apart. We actually ignore most of the things before us [...] To begin at the bottom, what are our very senses themselves but organs of selection?" (James 1950: I, 284).

18. James (1950: I, 285).

19. F. H. Bradley (1893: 25).

20. F. H. Bradley (1893: 31).

21. F. H. Bradley (1893: 32).

22. J. Royce (1900: Lecture VIII).

23. Id., Ibid.

24. James (2008: 126).

25. James (2008: 128-9).

26. For a synthetic view combining aspects of the doctrine of the intersubjective constitution of the "social order" of the Husserlian Phenomenology and William James's concept of consciousness see: Schutz 1962. Compare also with Gurwitsch 1964.

27. This was the point of departure of A. Schutz's research, partially connected to James's Psychology. Due to his debt to E. Husserl's Phenomenology and M. Weber's Sociology, Schutz's analyses of communication in society are subordinated to the methodological arch relating the subject, the action and the shared symbols. Compare Schutz \& Luckmann (1973: 148 ff.). Here, the connection with G. H. Mead's Mind, Self, and Society is evident.

28. With the concept of communication used along this text it is not meant an intersubjective intercourse of words between human beings. The concept is used with a larger meaning. By communication I mean a production of meaning effects that transcend the consciousness of the individuals and may have its source, dissemination and impact outside psychic systems or psychic environments. Additionally, the idea of a self-catalyzed system of communication comes from the work of N. Luhmann. See Luhmann 2001.

29. Some aspects of the research about the impact of Peirce's concept of sign and semeiosis in the World-image of the traditional Metaphysics were developed by K.-O. Apel (1973: 157-77) and L. Honnefelder 1990. Summarizing many readings of Peirce, see Ketner (1995: 315 ff.).

30. The Kantian influence was decisive in the years of the formation of the first sketches of the categories. In the text On a New List of Categories, a category was the conceptual result of the reduction of the multiplicity of the sensorial experience, also reflected in the different types of judgements. At the surface, Peirce's idea of a new deduction of categories continues what Kant called metaphysical deduction of the categories. However, Peirce was aware of the need for a special analysis of the signs implied in the judgements. Later, in the Lectures on Pragmatism, Lecture II, Peirce used the concept of "Phenomenology" to denote the discipline responsible for the examination of "the faculty of seeing." See 5.43. Under mixed presuppositions and new interpretations of a "science of ideas" or conceptions the philosopher recurred also to the words "Ideoscopy," in the Letters to Lady Welby (8.328), and "Phaneroscopy" (1.317-21; "The Basis of Pragmaticism in Phaneroscopy" in C. S. Peirce, N. Houser 1998: 360 ff.). See also W. L. Rosensohn 1993.

31. References to C. S. Peirce's Collected Papers will be along the text. The numbers refer volume and paragraph in the Harvard edition. 
32. The answer to Question 5 "Whether we can think without signs" is given in 5.251 as following: If we seek the light of external facts, the only cases of thought which we can find are of thought in signs. Plainly, no other thought can be evidenced by external facts. But we have seen that only by external facts can thought be known at all. The only thought, then, which can possible be cognized is thought in signs. But thought which cannot be cognized does not exist. All thought, therefore, must necessarily be in signs (5.251).

33. "Question 7 'Whether there is any cognition not determined by a previous cognition' [...] For something entirely out of consciousness which may supposed to determine it, can, as such, only be known and only adduced in the determinate cognition in question. So, that to suppose that a cognition is determined solely by something absolutely external, is to suppose its determinations incapable of explanation. Now, this is a hypothesis which is warranted under no circumstances, inasmuch as the only possible justification for a hypothesis is that it explains the facts, and to say that they are explained and at the same time to suppose them inexplicable is self-contradictory" (5. 260).

34. Earlier, in Consequences of four Incapacities he declared about the way in which the ideas return to a "first" beginning, less vivid than the actuality: "[...] These in their term have been derived from others still less general, less distinct, and less vivid; and so on back to the ideal first, which is quite singular, and quite of consciousness. This ideal first is the particular thing-in-itself. It does not exist as such" (5. 311).

35. "Some thoughts are produced by previous thoughts according to regular laws of association, so that if the previous thoughts be known, and the rule of association be given, the thought which is so produced may be pre- dicted. This is the elaborative operation of thought, or thinking par excellence. But when an idea comes up in the mind which has no such relation to former ideas, but is something new to us, we say that it is caused by something out of mind, and we call the process by which such thoughts spring up, sensation. And those parts of investigation which consist chiefly in supplying such materials for thought to work over, combine and analyze, are termed observations" (7. 328) "[...] But observations alone cannot constitute investigation [...] Accordingly, besides observation it must be that there is also an elaborative process of thought by which the ideas given by observation produce others in the mind" (7.331).

36. A consequence of the postulation of the "final belief" in the actual efforts to build knowledge is the ideal character of a community of research which operates in a way similar to a hypothesis in the heuristic drive of science: "Hypothesis is where we find some very curious circumstance, which would be explained by the supposition that it was a case of a certain general rule, and therefore adopt that supposition" (2.524).

37. The constitution of the continuity of knowledge through hypothetic guessing is especially emphasized in the fragment manuscript entitled Guessing. Here Peirce shows the power of the "generals" or universals in the formation of the "art of inquiry" (7.47), but also the value of vagueness.

38. In Consequences of Four Incapacities Peirce wrote: "The real, then, is that which, sooner or later, information and reasoning would finally result in, and which is therefore independent of the vagaries of me and you. Thus, the very origin of the conception of reality shows that this conception essentially involves the notion of a COMMUNITY, without definite limits, and capable of a definite increase of knowledge" (5.316-5.317).

39. The homogeneous medium attributed to the sign-thought couple is emphasized through the endless connectivity of its elements: "From the proposition that every thought is a sign, it follows that every thought must address itself to some other, must determine some other, since that is the essence of a sign" (5. 253).

40. The diagrams linking the three categories of firtsness, secondness and thirdness and the three components of semiosis, with its further divisions, makes clear that Peirce intends with his semiotic concept of thought a new idea of representation without rejecting the homogeneous 
medium of the ancient, medieval and modern Theory of Being as the ground for the modi essendi, cognoscendi and communicandi. Peirce used the kantian concept of "regulative principles" to describe the power of the representation of the future in the orientation in the present as a "logical principle" in the Notebook of the Lowell Lectures. See manuscript numbered MS 462, p. 25 Archive images, captured at Harvard 1994, by M. Keeler under NSF grant. Stored on DAT and transferred to the University of Washington in 1997. Archived on 1/98 at CARTAH, by M.Keeler on 6 CDs; CDs 1-5 ISO9660, CD 6 HFS. Towards the same direction goes his conception of abduction in 2.270 .

41. See E. Balsemão Pires (1993: 117-8).

42. Compare with the Manuscripts numbered MSS 460, MSS 462 and MSS 464. Archive images, captured at Harvard 1994, by M. Keeler under NSF grant. Stored on DAT and transferred to the University of Washington in 1997. Archived on 1/98 at CARTAH, by M.Keeler on 6 CDs; CDs 1-5 ISO9660, CD 6 HFS.

43. Compare: Sebeok 2001; Sebeok 1994; Johansen \& Larsen 2002; Petrelli \& Ponzio 2008.

44. See: Lotman 2001; Lotman \& Ouspenski 1976; Bains 2001; Deeley 2004; Nöth 2006.

45. Here the reference to the work of biologist J. von Uexküll and his concept of the biological Umwelt of the organisms is important. Compare: J. von Uexküll 1956; T. von Uexküll 1999; Barbieri 2008.

46. See Battail 2009.

47. Sebeok (1994: 139-49).

48. According to Luhmann (2001: 120-1).

49. The image of an "Architectonics of Semiosis" in an essay of E. Taborsky 1998 is seductive, because in the book the author tries to develop the idea of "semiotic complexity, ongoing diversification" (Taborsky 1998: 16) or "stages of increasing complexity of cognition" (Taborsky 1998: 114). But, a real diversification of semiosis demands the previous clarification of systemic individuation and constitution of meaning frontiers between systems and environments.

\section{ABSTRACTS}

The pragmatist turn in Philosophy in the late XIX century and XX century was a serious attempt to refuse the privilege of the representational elements of the conscious- ness in the production of knowledge. Such privilege has its roots in Ancient Philosophy, in some consequences of the Platonic heritage, but was toughened by Modern philosophers of empiricist or aprioristic lineages within the modern concepts of Experience and Truth. With these last concepts of Experience and Truth I'm referring to the objectivising tendency that leads to identify experience with the final object resulting from the judicative fixation of relations. Due to the fixation of some basic relations the object of experience was identified and conceived with such and such characteristics as something independent of the mental or judicative activity. Such method of fixation and objectivising of relations is also present in the common-sense ideas of Reality, Experience and Truth.

In the field of the theory of signs the reputation of the modern concept of representation was so vast that despite the progress in the discovery of the differential character of the linguistic units, Saussure's well-known notion of sign and the division between "signifiant" and "signifié" still kept the reference to the double across the body/mind polarity and to the "mental image" of the sign, Vorstellung, concept or "signifié," as the core of meaning. If Peirce and James agree in the 
refusal of the classical theory of representation, their rejection came from different horizons and their critiques don't mean the same.

I'll try to show that James's and Peirce's attempts are not disjunctive, although they are not members of a simple addition. In the writings of the Tartu School and in T. Sebeok's reassessment to Peircean semeiosis one finds interesting tools to reconsider the relation to the World of the "field of consciousness" and semeiosic cycles, beyond representationalism, such as the concepts of environment and primary, secondary and tertiary modelling systems. Starting with these insights I'll propose at the end of the essay the notion of a double environment between psychic systems and systems based on communication.

\section{AUTHOR}

\section{EDMUNDO BALSEMÃO PIRES}

Universidade de Coimbra

edbalsemao[at]gmail.com 